\title{
THE EFFECTIVENESS OF DICTOGLOSS IN TEACHING WRITING SKILL VIEWED FROM STUDENTS' MOTIVATION
}

\author{
Dian Pertiwi $^{1}$, Ngadiso $^{2}$, Nur Arifah Drajati ${ }^{3}$ \\ Sebelas Maret University, J1. Ir. Sutami No 36A, Surakarta, Indonesia \\ dianpertiwi384@yahoo.co.id
}

\begin{abstract}
This article refers to an experimental study on the effectiveness of Dictogloss to teach writing skill at one of Islamic School in Surakarta. The sampling used in this research was cluster random sampling with two classes as sample, namely experimental class taught using Dictogloss and control class taught using Direct Instruction. The collect the data, there were two instruments used in this research namely, writing test and motivation questionnaire. Writing test was used to find out students' writing skill, while motivation questionnaire was conducted to know students' motivation levels. The data were analyzed by using 2x2 Multifactor Analysis of Variance (ANOVA). Before conducting the ANOVA test, pre-requisite test namely normality and homogeneity test were conducted. The result of this research shows that: (1) Dictogloss is more effective than Direct Instruction to teach writing; (2) Students having high motivation have better writing skill than those having low motivation.
\end{abstract}

\section{Keywords: dictogloss, writing, motivation}

\section{INTRODUCTION}

Writing is one of the important language skills that should be mastered by the students to convey their ideas or their opinion in written form. In line with this view, Raimes (1983) states that writing is an important skill for students because of some reasons. First, writing strengthens the students' grammatical structure, idioms, and vocabulary. Second, writing gives a chance to students to apply the language they have learned. Third, writing reinforces students to express ideas in correct words and sentences. Therefore, students will be involved both in writing and thinking process. However, writing is not a simple matter to learn and it has been considered as a difficult task since a large number of students make a lot of mistakes and errors in their written texts and cannot create a coherent text.

Richards and Renandya (2002, p. 303) state that writing is the most difficult skill for second or foreign language learners to master. The difficulties are not only in generating and organizing ideas, but also in translating these ideas into a readable text. The difficulty becomes more noticeable if their language proficiency is weak. Moreover, Harmer (2007, p. 329) argues that some of students are not confident enough to write. The students lose their enthusiastic. The writer thinks that there are some reasons for students not to write, perhaps students have never written much in first language(s) or they do not have anything to say and cannot come up with the ideas.

To solve this problem, it seems that teachers should apply a kind of technique that suitable for learners. One of the teaching techniques is dictogloss which is a new version of dictation first introduced by Wajnryb in 1990. Dictogloss is different with the traditional dictation in which the teacher 
reads the text slowly and repeatedly and asks students to write exactly what the teachers read without doing any thinking.

In Dictogloss, there is a gap between listening and writing phases. A text is read twice to learners. They may not do anything except listening to the text at first reading and they are asked to take brief notes at second reading. Next, they work cooperatively in a group to reconstruct the text from their shared notes. The task of reconstruction the whole text dictated from their notes requires the students in groups to discuss and recall their prior knowledge about grammar, vocabulary, and language features of text that they have to use in their reconstructed text and they also have to organize well their shared notes and idea into paragraph form in order their reconstructed version will be coherent and have closely meaning to the original text. At last, they analyze and compare their various works to the original text each other.

By dictogloss, students can learn and train to write good paragraph/s in different way. Vasiljevic (2010) states that dictogloss also gives opportunities for students to learn something new from their group because every person in a group has different skill in writing. From the other members of groups, students can get feedback and correction to their mistakes in writing, so that they can identify their strengths and weaknesses in writing that can help them to produce better writing. Moreover, students can decrease their anxiety in learning writing because they work in a group.

Smith (2012, p. 2) states that Dictogloss allows learners to process and activate language in a collaborative writing task, promotes writing to learn (meaning making) rather than learning to write (skill), encourages learners to reflect on form, encourages L2 learners to think critically and take risks in their language use, and results in synchronous interaction which mean that students practice the target language more often. Therefore, dictogloss makes students learn more actively and successfully in writing class.

Lee and Jacobs (2001) consider the collaboration aspect of the dictogloss task and based on the journals and questionnaires collected from the students, they found that it has a positive effect on the learners in case of both recognition and effect. They concluded that a collaborative task like dictogloss can help learners be satisfied with working in groups, have better feelings and therefore learn better.

Collins (2007) in her article examines the issues of L1 influence and common developmental patterns in the domain of verb tense and aspect. It was found that Dictogloss and interpreting contexts seem to be useful as activities for verb tenses in a Japanese classroom.

Another thing that also influences the students' writing skill comes from other factors besides the teaching technique. It is the students' motivation. Motivation plays an important role on the development of the students' writing as it is a driving force for them to write in a meaningful way (Hamidun \& Hasyim, 2012, p. 591). Mahadi and Jafari (2012, p. 233) define that motivation as a physical, psychological or social need which motivates the individual to reach or achieve his goal and fulfill his need and, finally, feel satisfied owing to achieving his aim. It means that motivation is something arousing us to achieve the goal or fulfilling the need. They believe that motivation is important because 
it determines the extent of the learners' active involvement and attitude toward learning.

Related to the writing skill, the students who have high motivation will have motivation to learn something. The students become more motivated and have great enthusiasm to accomplish their goals in writing. On contrary, the students who have low motivation will have no interest in writing and they don't know how to write. The students will have difficulty in understanding the text given because they never try to find the solution. The students have low desire to learn and very passive. They do not have learning strategies for writing.

From the explanation above, the researcher interests to investigate whether or not Dictogloss is more effective than Direct Instruction to teach writing skill for the eleventh grade students, and to reveal whether or not students having high motivation have better writing skill than those having low motivation.

\section{LITERATURE REVIEW Writing}

Writing has always been seen as an important skill in ESL classes. It is the area in which learners are expected to be offered adequate time to develop their writing skill. Writing is certainly an important element of learning English as a second language. This importance is eventually derived from the fact that it reinforces grammatical structures, vocabulary and idioms that we have been teaching to our students (Ismail, 2011, p. 73). It is also supported by Brown (2004) who states that writing skill is an important skill for achieving employment in this global era. Thus, learning how to write for students is crucial as input for them to face the future.

According to Brown (2001, p. 335), writing is the written products of thinking, drafting, and revising that require specialized skills on how to generate ideas, how to organize them coherently, how to use discourse markers and rhetorical conventions coherently into a written text, how to revise text for clearer meaning and how to edit text for appropriate grammar and how to produce a final products.

Nunan $(2003$, p. 88$)$ defines writing as the process of thinking to invent ideas, thinking about how to express into good writing, arranging the ideas into good statement and paragraph clearly. Oshima and Houge (2006, p. 265) explain that writing is process of creating ideas, organizing them, writing a rough draft, and finally polishing the rough draft through editing and revisions.

From those explanations, it can be concluded writing is complex process of thinking, creating ideas, and organizing them into good statement and paragraph, and finally polishing the rough draft through editing and revision to produce a final products.

The nature of writing needs writing components that need to be master in order to be able to produce a successful writing. Brown (2000. p. 335) proposes five major aspects of writing that have to be acquired by a writer in producing a written text namely content, organization, vocabulary use, grammatical use, and mechanical consideration such as spelling and punctuation. Meanwhile, there are four common stages in writing process; those are planning, drafting, editing, and producing final version (Harmer, 2004, p. 4-5). 
Dictogloss

Vasiljevic (2010, p. 41) states that dictogloss is a classroom dictation activity where the students listen to the passage, note down key words, and then work in group to create a reconstructed version of the text in the form of writing.

The steps followed in Dictogloss tasks are described as:

Preparation: Students will be prepared for the task by being involved in a discussion and vocabulary presentation related to the topic.

Dictation: Teacher will read the text twice at natural speed. Students will take notes while listening in order to be able to reconstruct the text read to them.

Reconstruction: Students will be arranged in small groups or pairs. They will pool their notes and reconstruct their own version of the passage. During this step, teacher will not provide them with any information.

Analysis/ Feedback: During this stage, students' writings will be corrected first by the teacher just by giving them some codes, and then students will compare their own version with the original one to be informed about their mistakes and be able to correct them

Dictogloss procedure is particularly useful in helping students rely on their memory and apply their vocabulary and grammar knowledge in writing. In this connection R. Wajnryb states that during the Dictogloss procedure, because of the speed of the reading and the density of the text, the language learners manage to produce a fragmented text where the essential cohesion is missing. As a result there exists an "information gap" which should be filled in the reconstructing process by relying on the memory as well as the creativity of the language learner (Wajnryb, 1990).

\section{Motivation}

Motivation is an important aspect in learning language. It affects students' attitude toward the learning process. Mahadi and Jafari (2012, p. 233) define motivation as a physical, psychological or social need which motivates the individual to reach or achieve his goal and fulfill his need and, finally, feel satisfied owing to achieving his aim. It means that motivation is something arousing us to achieve the goal or fulfilling the need. Similar to this, Kumaravadivelu (2006, p. 66) states that motivation is an internal feeling that arouses one to do action, triggers one to a certain direction, and pertains one to be engaged in certain activities.

There are two different kinds of motivation: intrinsic and extrinsic. Intrinsic motivation is defined as the doing of an activity for its inherent satisfaction rather than for some separable consequence. When intrinsically motivated, a person is moved to act for the fun or challenge entailed rather than because of external products, pressures or rewards (Ryan and Decy, 2000, p. 56). Extrinsically motivated behaviors, on the other hand, are carried out in anticipation of reward from outside and beyond itself. Typical extrinsic rewards are money, prizes, grades and even certain types of positive feedback. Behaviors also initiated extrinsically motivated, even though numerous intrinsic benefits can ultimately accrue to those instead, view punishment avoidance as a challenge which can build their sense of competence and self-determination (Brown, 2000, p.164). 
There are many factors affecting students' motivation and students' achievement considerably on the basic of establishing effective and efficient learning-teaching process in education systems. The studies show many motivational factors (psychological, social, and cultural): intrinsic and extrinsic directions, parental influence and participation, family history, peer pressure, self-efficacy expectations, effort, value attributed to be a relative, anxiety, selfregulation and determination of goals, talent perceptions, learning strategies, teaching style and school environment (Brophy, 1998, Garcia, 1995, Nolen and Haladyna, 1989, Pintrich and Schunk, 1996, Singh, Granville and Dika, 2002). For example, it is stated that the school environment optimizes motivation and learning when it is accessible, secure, positive, personalized and empowering. Teachers here, of course, play a very important role because they are an integral part of the school environment. Researcher indicates that teacher's knowledge and skills, motivation level, qualifications, forms of evaluation, teaching style, quality of enthusiasm and enthusiasm can contribute to the motivation of the learners. The more enthusiastic, motivated and qualified teachers are in teaching and evaluating, the greater the capacity to increase learners' motivation to learn (William and William, 2011). Furthermore, lack of participation in the parents' education of the students because studies indicate that there is significant relationship between parent involvement and children's academic motivation and educational development (Gottfried \& Gottfried, 1994).

\section{Research Method}

This research was conducted at one of Islamic school located in Surakarta. This study was conducted on February to April 2018. The research method used in this research was an experimental study. The design of this research was a simple factorial design $2 \times 2$ with post-test only design. This research involved three kind of variables namely independent variable (teaching techniques), dependent variable (writing skill), and attribute variable (students' motivation). The target population was the eleventh grade students. The sampling used in this study was cluster random sampling. In this research, the researcher took two classes from four classes of the eleventh grade students as sample. One class was experimental group taught by Dictogloss and the other was control group taught using Direct Instruction.

In this research, the researcher used two instruments in collecting data. They were writing test and motivation questionnaire. Writing test was used to find out students' writing skill and motivation questionnaire was conducted to know the level of students' motivation. Both instruments were assessed by using readability of test instruction, validity and reliability of motivation questionnaire. The questionnaire must be valid and reliable before it is administered in experimental and control class. After the writing scores were obtained, they were sorted in accordance with students' motivation levels, high and low. The techniques used in analyzing the data of this study were descriptive and inferential analysis. Descriptive analysis is used to find out the mean, median, and standard deviation of the writing test. Before testing the hypothesis, normality and homogeneity test were conducted. Then, it was followed by testing the research hypothesis using inferential analysis of variance $2 \times 2$ (ANOVA). 


\section{Research Finding and Discussion}

The data of this research are distributed into eight groups: (1) the data of the writing test of the students who are taught using Dictogloss (A1); (2) the data of the writing test of the students who are taught using Direct Instruction (A2); (3) the data of the writing test of the students having high motivation (B1); (4) the data of the writing test of the students having low motivation (B2); (5) the data of the writing test of the students having high motivation who are taught using Dictogloss (A1B1); (6) the data of the writing test of the students having low motivation who are taught using Dictogloss (A1B2); (7) the data of the writing test of the students having high motivation who are taught using Direct Instruction (A2B1); (8) the data of the writing test of the students having low motivation who are taught using Direct Instruction (A2B2).

The data are analyzed by using Multifactor Analysis of Variance (ANOVA) $2 \times 2$. Before that, the normality and homogeneity of the data should be tested as the requirement to use ANOVA. The result of normality using Liliefors test shows that all data are normal. As it can be seen by comparing the values gained (Lo) and Lt, where the values (Lo) are lower than Lt. Thus, it can be concluded that the data on both teaching techniques and motivation levels normaly distributed. The computation of normality test is devided into eight groups of data summarized as follows:

Table 1. The Summary of Normality Test

\begin{tabular}{|c|l|c|c|c|c|c|}
\hline No & \multicolumn{1}{|c|}{ Variables } & $\mathrm{N}$ & Lo & Lt & Test Decision & Status \\
\hline 1 & $\begin{array}{l}\text { The writing scores } \\
\text { of the students } \\
\text { taught by using } \\
\text { Dictogloss (A })\end{array}$ & 26 & 0.0782 & 0.173 & $\mathrm{H}_{\mathrm{o}}$ is accepted & Normal \\
\hline 2 & $\begin{array}{l}\text { The writing scores } \\
\text { of the students } \\
\text { taught by using } \\
\text { Direct Instruction } \\
\text { (A })\end{array}$ & 26 & 0.1286 & 0.173 & $\mathrm{H}_{\mathrm{o}}$ is accepted & Normal \\
\hline 3 & $\begin{array}{l}\text { The writing scores } \\
\text { of the students } \\
\text { having high level of } \\
\left.\text { motivation (B } \mathrm{B}_{1}\right)\end{array}$ & 26 & 0.1210 & 0.173 & $\mathrm{H}_{\mathrm{o}}$ is accepted & Normal \\
\hline 4 & $\begin{array}{l}\text { The writing scores } \\
\text { of the students } \\
\text { having low level of } \\
\left.\text { motivation (B } \mathrm{B}_{2}\right)\end{array}$ & 26 & 0.1061 & 0.173 & $\mathrm{H}_{\mathrm{o}}$ is accepted & Normal \\
\hline 5 & $\begin{array}{l}\text { The writing scores } \\
\text { of the students } \\
\text { having high level of } \\
\text { motivation taught } \\
\text { using Dictogloss } \\
\text { (A } \mathrm{B}_{1} \text { ) }\end{array}$ & 13 & 0.1070 & 0.245 & $\mathrm{H}_{\mathrm{o}}$ is accepted & Normal \\
\hline 6 & $\begin{array}{l}\text { The writing scores } \\
\text { of the students }\end{array}$ & 13 & 0.0816 & 0.245 & $\mathrm{H}_{\mathrm{o}}$ is accepted & Normal \\
\hline
\end{tabular}




\begin{tabular}{|c|l|l|l|l|l|l|}
\hline & $\begin{array}{l}\text { having low level of } \\
\text { motivation taught } \\
\text { using Dictoglos } \\
\left(\mathrm{A}_{1} \mathrm{~B}_{2}\right)\end{array}$ & & & & & \\
\hline 7 & $\begin{array}{l}\text { The writing scores } \\
\text { of the students } \\
\text { having high level of } \\
\text { motivation taught } \\
\text { using Direct } \\
\text { Instruction }\left(\mathrm{A}_{2} \mathrm{~B}_{1}\right)\end{array}$ & 13 & 0.1271 & 0.245 & $\mathrm{H}_{\mathrm{o}}$ is accepted & Normal \\
\hline 8 & $\begin{array}{l}\text { The writing scores } \\
\text { of the students } \\
\text { having high level of } \\
\text { motivation taught } \\
\text { using Direct } \\
\text { Instruction }\left(\mathrm{A}_{2} \mathrm{~B}_{2}\right)\end{array}$ & 13 & 0.1736 & 0.245 & $\mathrm{H}_{\mathrm{o}}$ is accepted & Normal \\
\hline
\end{tabular}

Besides, the result of homogeneity test show that $\chi_{o}{ }^{2}(1.921)$ is lower than $\chi_{t}{ }^{2}(7.815)$ at the level of significance $\alpha=0.05$ or $\chi_{o}{ }^{2}<\chi_{t}{ }^{2}(1.921<$ $7.815)$, it can be conclude that the data are homogeneous. It means the data obtained from the results for both variables are homogenous. After finding normality and homogeneity of the data, the data are analyzed by using Multifactor Analysis of Variance (ANOVA) 2x2. This test used to know the effect of the independent variable and attributive variable toward the dependent variable. Besides, ANOVA has function to know if there is interaction among the variables. The hypothesis is rejected if Fo is higher than $\mathrm{Ft}(\mathrm{Fo}>\mathrm{Ft})$. The result of the data is presented in the table below.

Table 2. The Mean Scores

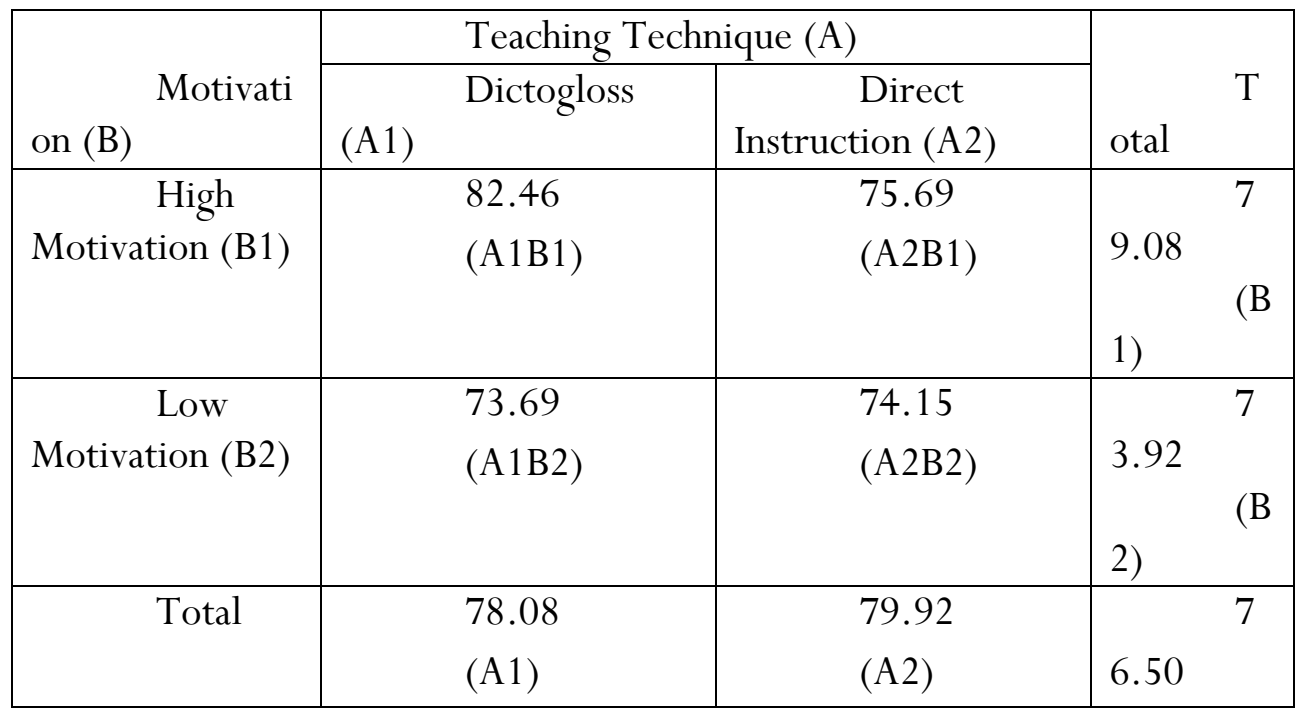


Table 3. Summary of a 2x2 Multifactor Analysis of Variance

\begin{tabular}{|c|c|c|c|c|c|}
\hline Source of Variance & SS & $\mathrm{f}$ & $\mathrm{S}$ & $\mathrm{O}$ & $\mathrm{t}(0,05)$ \\
\hline Between Columns & 9.31 & & 29.31 & .43 & .08 \\
\hline Between Rows & 5.31 & & 45.31 & 1.82 & 4.08 \\
\hline Interaction & 9.92 & & 69.92 & .82 & 4.08 \\
\hline Between Group & 4.54 & & 14.85 & & \\
\hline Within Group & $02.46^{14}$ & 8 & 9.22 & & \\
\hline Total & $47.00^{20}$ & 1 & & & \\
\hline
\end{tabular}

Because Fo between columns (4.43) is higher than Ft (4.08) at the level of significance $\alpha=0.05$, Ho is rejected and the difference between columns is significant. Thus, it can be concluded that there is a significant difference on the students' writing skill between those who are taught using Dictogloss and those who are taught using Direct Instruction. Based on the computation result, the mean score of students who are taught using Dictogloss (78.08) is higher than that of those who are taught using Direct Instruction (74.92). It can be concluded that Dictogloss is more effective than Direct Instruction to teach writing skill.

Because Fo between rows (11.82) is higher than Ft (4.08) at the level of significance $\alpha=0.05$, Ho is rejected and the difference between rows is significant. It can be concluded that students having high motivation differs significantly from those who are have low motivation in their writing skill. In addition, the mean score of students who have high motivation (79.08) is higher than that of those who have low motivation (73.92). It can be concluded that the students having high motivation have better writing skill than those who have low motivation.

The following section discusses findings of the research by considering the result of the data analysis above:

\section{The differences between Dictogloss and Direct Instruction to teach writing}

The research findings reveal that there is a significant difference between Dictogloss and Direct Instruction. The result shows that Dictogloss is more 
effective than Direct Instruction to teach writing. The mean score of students who are taught by using Dictogloss is higher than students who are taught by using Direct Instruction.

Teaching writing skill by using Dictogloss makes students learn more actively and successfully in writing class. Dictogloss also lets students do individual and group activities and gives multiple opportunities for peer learning and peer teaching. In reconstruction stage of Dictogloss, the students work in a group to reconstruct the text dictated through discussion. Moreover, in analysis and correction stage of Dictogloss, the students' reconstructed texts are analyzed and corrected by their friends who enable students to see what they have done well and what they need to know more about writing. Therefore, the students with low ability in writing can learn from their friends who have higher ability in writing so their writing can be improved.

Dictogloss involves four phases namely preparation, dictation, reconstruction, and analysis and correction. These stages can lead to oral communicative activities among language learners. After reconstructing their own version of the dictated text, the students are asked to read them aloud, analyze the used words, phrases and the grammatical constructions, compare their written works with the original text as well as with their peers' works, work in small groups and discuss the results and share opinions about them. Thus, Dictogloss activities result an interaction, collaboration, and empowerment. This completely changes the patterns of activity in a class that to be a teacher-centered.

Vasiljevic (2010) stated that by dictogloss, students can learn and train to write good paragraph/s in different way. Students are given much time to interact with their friends during learning. Dictogloss also gives opportunities for students to learn something new from their group because every person has different skill in writing. From the other members of groups, the students can get feedback and correction to their mistakes in writing, so that they can identify their strengths and weaknesses in writing that can help them to produce better writing. Moreover, students can decrease their anxiety in learning writing because they work in a group.

This also supported by previous research done by Farid, Setyarini, and Moecharam (2017). The research was to find out how Dictogloss storytelling enhances the students' writing ability. The analysis of student texts showed that the implementation of Dictogloss storytelling led to the improvement of students' writing performance, not only in terms of score, but also in terms of its schematic structure, content, and language. Students wrote narrative schematic structure in a better organization. The content was improved, in which students were able to write detail events in proper order. In terms of the use of language, error in 
grammar, vocabulary, and spelling, and punctuation, it did not occur as frequently as in students' pre-test writing. Moreover, the findings of interview demonstrated that the students enjoyed learning activities using Dictogloss storytelling technique. This technique helped students to enrich their vocabulary and complete the writing task given by the teacher. Furthermore, Dictogloss storytelling enabled students to actively participate in the learning activities. This was supported by the classroom observation result; it revealed that students were actively giving a response to the characters of the story, they enthusiastically responded to the questions asked by the teacher and showed great participation in groups.

Another research result was from Lee and Jacobs (2001). They considered the collaboration aspect of dictogloss task and based on the journals and questionnaires collected from the students, they found that it has a positive effect on the learners in case of both recognition and effect. They concluded that a collaborative task like dictogloss can help learners be satisfied with working in groups, have better feelings and therefore learn better.

On the contrary, in Direct Instruction, the students are the objects of learning. They are passive students rather than active since they fully depend on the teacher's instruction and guidance, they listen to the teacher's instruction and do the things required by the teacher. Teacher plays an important role in this technique. Teacher is as resource of information and knowledge. It is stated by Parsons, Hinson, and Brown (2001, p. 11) that Direct Instruction is teachercentered model. This means that the teacher becomes major information, and all the activities are under the teacher's control. The material is determined by the teacher, which means that the students have less opportunity to learn from others.

Some researcher (Gagne, as cited in Magliaro, Loocke, \& Barton, 2005) posited that Direct Instruction should be not be used for higher level learning or performance, but in situations where motor skills or prerequisite intellectual skills are being instructed. This would be: Mathematical producers, grammar rules, scientific equations, etc. As stated in research conclusion employed by Ryder, Burton, \& Silberg (2006) that Direct Instruction approaches can be tied to three principles; language is broken down into components taught in isolation; learning is teacher-directed; and students have little input.

Based on the elaboration above, it can be concluded that Dictogloss is more effective than Direct Instruction in teaching writing skill.

The differences between students having high motivation and students having low motivation. 
The findings of this research reveal that students having high motivation have better writing skill than those having low motivation. The mean score of students having high motivation is higher than that of having low motivation.

High motivated students tend to be more active in the teaching learning process because they have strong desire to learn. They are curious, enthusiastic joining teaching learning process. They are good at making full use of every chance to improve them. They have desire to learn and continue to influence the students' conscious decision to act and the effort that they will put into learning. Learning is not a burden for them but a moment of enjoyment, they feel very happy to learn, and the efficiency is greatly improved. It is supported by Gardner (2005, p. 4) that high motivation display many characteristics. Motivated individuals express effort in attaining the goal, they show persistence, and they attend to the tasks necessary to achieve the goals. They have strong desire to attain their goal, and they enjoy the activities necessary to achieve their goal. They are aroused in seeking the goals, they have expectancies about their successes and failure, and when they are achieving some degree of success they demonstrate self-efficacy; they are self-confident about their achievement. Finally, they have reasons for their behavior.

Qin \& Wen (2002, p. 54) stated that high-motivated students use learning strategies more frequently, have a stronger will to learn, and thus set more and higher goals for themselves, and they are more persistent in learning. Similar views, Martens (2004, p. 622) posited that high-motivated students are more persistence, and more likely to achieve set goals, and have higher levels of selfregulation. The students are more curious and engage in more deep level learning, an effect that holds true for students of all age group.

This also supported by previous research done by Waite \& Davis (2006). They found that the students showed a higher level of motivation when they planned meetings and discussed problems within a supportive group of similarly motivated individuals. This finding shed light on instructional methods that provide a strategic approach to promote learning through collaborative interaction. Students may well perform better when they feel they belong and share interests with their teachers in acquiring the knowledge, skills, and abilities that engender academic success. That is, intrinsically motivated students, when working together, may mutually help each other's learning beyond the level of that seen in extrinsically motivated individuals. The instructional methods teachers employ play an essential role in deciding the motivational orientation of their students.

On the contrary, students who have low motivation tend to be passive recipients of knowledge; they only receive what teacher said. They always depend 
on someone else, do not try hard, give up easily in the face of challenge, and do not have desire to improve their competencies. Students who have low motivation tend to be discouraged to participate or involve in learning activity, lazy to learn, and get bored easily in classroom. They cannot be motivated to perform well because of their low interest to solve the problem, or the desire to understand during the lesson. There is no energy and a mental power from the students to reach the goal.

According to Lai (2012, p. 9), low-motivated students tend to procrastination, to make excuses, to avoid challenges tasks, and not to try, in an attempt to avoid negative ability attributions for tasks they are not confident they can perform. Moreover, Pelletier (2006, p. 569) described that unmotivated students lead to poor academic achievement, they are not interested in the challenges; they often fail because of low self-efficacy (effort, persistence, and goal setting).

This condition is appropriate with the previous study conducted by Trong Tuan (2011) that unmotivated learners show a lack of interest in the L2 or L2 community culture, hesitate to participate in any class activities, have no intimate affiliation with the teacher and/or peers. Consequently, they show ever-growing diffidence in classroom environment. Eventually, these learners end up with appalling learning outcomes, which in turn aggravate remaining motivation.

\section{Conclusion and Suggestions}

Based on the result of this study, the researcher draws some reseach findings: (1) Dictogloss is more effective than Direct Instruction to teach writing; (2) Students having high motivation have better writing skill than those having low motivation.

Besided, it is suggested that: (1) In relation to the teacher's performance, it is suggested that teachers should have a good understanding on the proper application of Dictogloss in teaching writing. Therefore, this technique can be implemented properly as the value and theory of Dictogloss. Moreover, teachers should prepare the material and activity to ensure the efficiency of the classroom activity during the teaching learning process. Teachers also need to manage the time effectively, so that both the teacher and students can enjoy the lesson; (2) it is important to take into consideration the group size because students must have the equal opportunity to share their ideas during discussion. The pronunciations of the teacher also need to be considered. The more fluent the teacher, the students will be easier to catch the sentences. For future similar research, the use of video recording is a great idea for better improvement; (3) for further research; this research can be additional references, especially for conducting the same kind of 
research related to teaching writing; (4) the writer hopes that other researchers will make such an improvement by trying to use this topic of research with different subjects of research and different psychological points of view besides motivation which may have correlation with students' writing skill.

\section{References}

Arends, R. I. (2004). Learning to Teach. New York: Mcgraw Hill Companies, Inc.

Brown, H. D. (2000). Principles of Language Learning and Teaching. London: Longman

Brown, H. D. (2001). Teaching by Principle. London: Longman

Brown, H. D. (2004). Language Assessment Principle and Classroom Practices. White Plains, NY: Pearson Education.

Bropgy, J. (1998). Motivating students to learn. Madison, WI: McGraw Hill.

Cohen, M. T. (2008). The Effect of Direct Instruction versus Discovery Learning on the Understanding of the Science Lesson by Second Grade Students. NERA Conference Proceeding 2008.

Collins, L. (2007). L1 differences and L2 similarities: Teaching verb tenses in English. English Language Teaching Journal, 61(4), 295-303.

Emily, R. Lai. (2012). Motivation: a literature review. Pearson.

Farid, A. A. P. A., Setyarini, S., \& Moecharam, Y. (2017). The implementation of Dictogloss Storytelling in improving 8th Grade Students' Writing Skill. Journal of English and Education. 5(1), 85-91

Garcia, T. (1995). The role of motivational strategies in self-regulated learning. New Directions for Teaching and Learning, 63, 29-42.

Gardner, R. C. (2006). The socio-educational model of second language acquisition: a research paradigm. EUROSLA Yearbook, 6, 237-260

Gottfried, A. E., Fleming, J. S., \& Gottfried, A. W. (1994). Role of parental motivational practices in children's academic intrinsic motivation and achievement. Journal of Educational Psychology, 86(1), 104-113.

Harmer, J. (2004). How to Teach writing. Malaysia: Longman.

Harmer, J. (2007). The Practice of English Language Teaching. ( $4^{\text {th }}$ edition). Harlow: Longman.

Ismail, A. A. S. D. (2011). Exploring Students' Perceptions of ESL Writing. English Language Teaching, 4(2), 73-83

Kumaravadivelu, B. (2006). Understanding Language Teaching From Method to Postmethod. London: Lawrence Erlbaum Associates.

Lim, W. L., \& Jacobs, G. M. (2001). An analysis of students' dyadic interaction on a dictogloss task. ERIC Document Reproduction Service No. ED 456-649

Magliaro, S. G., Lockee, B. B., \& Burton, J. K. (2005). Direct Instruction revisited: A key model for instructional technology. Journal of Education Research Technology and Development, 53, 41-55

Mahadi TS, Jafari SM. (2012). Motivation, its types, and its impacts in language learning: International. Journal of Business and Social Science. 3(24): 231-233. 
Nolen, S. B., \& Haladyna, T. M. (1989, March). Psyching out the science teacher: students' motivation, perceived teacher goals and study strategies. Paper presented at the annual meeting of the American Educational Research Association, San Francisco, CA.

Nunan, David. (2003). Practical English Language Teaching. New York: The McGraw Hill.

Oshima, A., \& Hogue, A. (2006). Writing Academic English. New York: Longman.

Parsons, R. D., Hinson, S. L., \& Sardo-Brown, D. (2001). Educational psychology: A practitioner-researcher model of teaching. Wadsworth Pub Co.

Pelletier, L. (2006). Why Do High School Students Lack Motivation in the Classroom? Toward an Understanding of Academic Amotivation and the Role of Social Support. Journal of Education Psychology, Vol. 98, No. 3, 567-582.

Pintrich, P. R., \& Schunk, D. H. (1996). Motivation in education: Theory, research, and applications. Englewood Cliffs, NJ: Merrill Company.

Qin, X., \& Wen, Q. (2002). Internal Structure of EFL Motivation at the Tertiary Level of China. Foreign Language Teaching and Research, 34, 51-58)

Raimes, A. (1983). Teaching foreign language skills. Chicago: Chicago University.

Richards, J. C. \& V. A. Renandya. (2002). Methodology in the Language Teaching: An Anthology of Current Practice. Cambridge: Cambridge University Press.

Ryan R. M., Deci E. L. (2000). Intrinsic and extrinsic motivations: classic definitions and new directions. Contemporary Educational Psychology. 25, 54-67.

Ryder, R. J., Burton, J. L., \& Silberg, A. (2006). Longitudinal Study of Direct Instruction Effects from First through Third Grades. Journal of Educational Research, 99(3), 179-191.

Smith, M. K. (2012). Dictogloss: A multi-Skill Task for Accuracy in Writing through Cooperative Learning. A Paper. Mensei University. Japan.

Singh, K., Granville, M., \& Dika, S. (2002). Mathematics and science achievement: Effects of motivation, interest, and academic engagement. The Journal of Educational Research, 95,323-332.

Trong Luan, L. (2011). EFL Learners Motivation Revisited. Theory and Practice in Language Studies, 1(10), 1257-1272.

Waite, S., \& Davis, B. (2006). Developing undergraduated research skills in a faculty of education: motivation through collaboration. Higher Education Research \& Development, 25(4), 403-419.

Wajnryb, Ruth. (1990). Resource Books for Teachers: Grammar Dictation. Oxford: Oxford University Press.

Weiner, B. (2000). Intrapersonal and Interpersonal Theories of Motivation from an Attributional Perspective. Educational Psychological Review, $12(1), 1-14)$ 
Dictogloss in Teaching

Williams, K. C., \& Williams, C. C. (2011). Five key ingredients for improving students motivation. Research in Higher Educational Journal, 12(1), 11-12

Vasiljevic, Z. (2010). Dictogloss as an Interactive Method of Teaching Listening Comprehension to L2 Learners. English Language Teaching, 3 (1), 1-12. 